\title{
Biochemical Variability and Seed Yield of Resistant and Susceptible Black Gram (Vigna mungo (L.) Hepper) Genotypes Elicited by Bemisia tabaci (Gennadius)
}

\author{
B. Rajitha", V. Rajarajeswari, P. Sudhakar, N.V. Naidu, \\ T.N.V.K.V. Prasad and B.V. Bhaskara Reddy
}

Department of Crop Physiology, S.V. Agricultural College, Tirupati-517502, A.P., India

*Corresponding author

\begin{tabular}{|c|}
\hline Keywords \\
\hline $\begin{array}{l}\text { Blackgram, Yellow } \\
\text { mosaic virus, Tolerant } \\
\text { and susceptible, } \\
\text { Biochemical changes }\end{array}$ \\
\hline Article Info \\
\hline $\begin{array}{l}\text { Accepted: } \\
26 \text { July } 2018 \\
\text { Available Online: } \\
10 \text { August } 2018\end{array}$ \\
\hline
\end{tabular}

\section{Introduction}

Plants face several challenges in terms of biotic stress due to insect pests. However, plants make use of a wide range of physiochemical mechanisms to protect themselves against such biotic stresses induced by insect pests. The resistance strategies could be constitutive, that is, they are always present in the plant independent of herbivore attack, or inducible, activated only
A field experiment was conducted at Dryland Farm of S.V. Agricultural College, Regional Agricultural Research Station, Acharya N.G. Ranga Agricultural University, Tirupati during rabi season, 2016-17. The study aimed to characterize blackgram genotypes for biochemical variability for YMV tolerance and susceptibility under yellow mosaic disease infection. In the present study, treatments consist of totally ten blackgram genotypes (5 known tolerant +5 known susceptible). Biochemical parameters viz., total chlorophyll, total phenols, total soluble sugars and total proteins were estimated spectrophotometrically from leaf samples collected at 30 and 50 days after sowing (DAS) from whitefly infested and uninfested plants. The parameters showed different activity levels at different times er the infestation. The tolerant genotypes recorded significantly higher mean total chlorophyll and total phenols as well as lower mean total soluble sugars and total proteins compared to susceptible genotypes. Among the genotypes TBG- 104 and LBG- 752 showed higher YMV tolerance compared to other genotypes. Among all the ten genotypes LBG-752 and recorded 21.41 per cent higher seed yield followed by TBG-104 and PU-31 compared to mean value of ten genotypes. Genotypes PBG- 1, LBG-623 and LBG-685 (susceptible genotypes) recorded lower seed yield compared to other genotypes. 
in tropical and subtropical regions of the world and is valued for easily digestible protein in its seeds. The crop is damaged by a number of insect pests during successive stages of the growth right from root nodules to flowers and pods, however whitefly B. tabaci appears as a major pest on black gram. The avoidable losses due to $B$. tabaci and other insect pests in blackgram have been reported to range from 17.42 to 71 per cent at different locations (Mansoor et al., 1998).

Screening of genotypes for resistance to insect pests has received considerable attention; however, there is limited progress in characterization of biochemical mechanisms conferring resistance to insects. Currently, the information on biochemical mechanisms and induced resistance in blackgram in response to whitefly is scarce. The present study was undertaken to determine changes in concentration of chlorophylls, phenols, total soluble sugars and proteins in blackgram due to yellow mosaic virus (YMV).

\section{Materials and Methods}

A field experiment was conducted at S.V. Agricultural College Farm, Tirupati campus of Acharya N.G. Ranga Agricultural University, during rabi season, 2016-17 which is geographically situated at $13.5^{\circ} \mathrm{N}$ latitude and $79.5^{\circ} \mathrm{E}$ longitude, with an altitude of $182.9 \mathrm{~m}$ above the mean sea level in the Southern Agro-Climatic Zone of Andhra Pradesh. Treatments consist of totally ten blackgram genotypes (5 known tolerant +5 known susceptible) obtained from Regional Agricultural Research Station (Lam) and Regional Agricultural Research Station (Tirupati). The experiment was laid out in a Randomized Block Design (RBD) with ten genotypes and replicated thrice. Genotypes consist of LBG-752, PU-31, LBG-792, GBG1, TBG-104, LBG-645, LBG-623, LBG-685, PBG-32 and PBG-1.
The experiment was conducted in a sandy loam soil with a plot size of $3 \times 3 \mathrm{~m}$. The crop was sown on $26^{\text {th }}$ October 2016 during rabi, 2016-17 with a spacing of $30 \times 10 \mathrm{~cm}$. Fertilizers were applied to the experimental plots with $20 \mathrm{~kg} \mathrm{ha}^{-1} \mathrm{~N}_{2}$ and $40 \mathrm{~kg} \mathrm{ha}^{-1} \mathrm{P}_{2} \mathrm{O}_{5}$ in the form of Urea and Single super phosphate as basal dose. Hand weeding and hoeing was done twice at 20 days interval after sowing. Need based irrigations were given at $5 \mathrm{~cm}$ depth. YMV infection was observed at 30 DAS. Biochemical parameters of blackgram genotypes influenced by yellow mosaic virus infection were recorded at 30 and 50 DAS.

\section{Estimation of total chlorophyll content (mg $\left.\mathrm{g}^{-1}\right)$}

Chlorophyll content was estimated by soaking $0.1 \mathrm{gm}$ of fresh leaf sample in $10 \mathrm{ml}$ Dimethyl sulfoxide for 24 hours in dark. Then light absorbance values were recorded at $645 \mathrm{~nm}$ and $663 \mathrm{~nm}$ using UV 2450 visible spectrophotometer. The chlorophyll content was calculated by using the formula given by Arnon (1949).

Total Chlorophyll $\left(\mathrm{mg} \mathrm{g}^{-1}\right.$ tissue $)=[20.2$ (D645) +8.02 (D663)] x V/1000 x W

Where,

$\mathrm{V}=$ Volume made up

$\mathrm{W}=$ Weight of leaf sample

\section{Estimation of phenol content $\left(\mathrm{g} \mathrm{g}^{-1}\right)$}

The phenol content was estimated using FolinCiocalteau reagent. $80 \%$ ethanol was used for extraction of phenols. One $\mathrm{g}$ plant material was ground in two $5 \mathrm{ml}$ portions of $80 \%$ ethanol and centrifuged. The extracts were pooled and made up to $10 \mathrm{ml} .0 .1 \mathrm{ml}$ of ethanol extract was evaporated on a water bath, to which $6 \mathrm{ml}$ water was added and shaken well before addition of $0.5 \mathrm{ml}$ Folin-Ciacalteau 
reagent. After $5 \mathrm{~min}, 2 \mathrm{ml}$ of $20 \%$ sodium carbonate solution was added. After incubation for $30 \mathrm{~min}$, absorbance at $660 \eta \mathrm{m}$ was measured. Using pyro catecholas standard, the phenol content in the leaf extract was calculated (Anonymous, 1965).

\section{Estimation of Total Soluble Sugars (TSS) (g} $\left.\mathrm{g}^{-1}\right)$

Total Soluble Sugars were estimated by Anthrone method given by Sadasivam and Manickam (1992). Total soluble sugars are first hydrolyzed into simple sugars using dilute hydrochloric acid. In hot acidic medium, glucose is dehydrated to hydroxymethyl furfural. This compound forms with anthrone, a green colored product with an absorption maximum at $630 \mathrm{~nm}$.

\section{Estimation of total protein content $\left(\mathrm{mg} \mathrm{g}^{-1}\right)$}

Total protein was estimated calorimetrically as per the method developed by Lowry et al., (1951) and recording absorbance at $595 \mathrm{~nm}$. Bovine serum albumin was used as standard. Protein content in leaf samples was recorded as $\mu \mathrm{g}$ of protein per $\mathrm{g}$ of leaf.

\section{Results and Discussion}

The results of present investigation revealed existence of genotypic variability among the genotypes tested for biochemical parameters at 50 DAS and yield at harvest (Table 1).

\section{Total chlorophyll content ( $\left.\mathrm{mg} \mathrm{g}^{-1}\right)$}

Indicate a loss of total chlorophyll content due to virus infection in blackgram plants. Significant differences were observed among genotypes. Tolerant genotypes recorded higher mean chlorophyll content compared to susceptible genotypes. The mean value of chlorophyll content was 24.07 per cent higher in tolerant genotypes compared to susceptible genotypes. Similarly Devi (2016) reported that in MYMV lower chlorophyll content was recorded in susceptible genotype LBG- 623 compared to other genotypes. Among all the ten genotypes TBG-104 recorded higher chlorophyll content of $1.295 \mathrm{mg} \mathrm{g}^{-1}$ followed by LBG- 752 and PU-31.

Among the tolerant blackgram genotypes TBG-104 showed higher chlorophyll content of $1.295 \mathrm{mg} \mathrm{g}^{-1}$ and GBG-1 showed lower chlorophyll content $\left(0.928 \mathrm{mg} \mathrm{g}^{-1}\right)$ whereas in susceptible genotypes LBG- 645 recorded higher chlorophyll content of $1.065 \mathrm{mg} \mathrm{g}^{-1}$ and PBG-1 recorded lower chlorophyll content (0.836 $\left.\mathrm{mg} \mathrm{g}^{-1}\right)$. Virus induced chlorosis in plants is generally attributed due to inhibition of chloroplast development and stimulation of the enzyme chlorophyllase which attack chlorophyll. It was reported that the virus infected yellow patches in blackgram leaves had much higher chlorophyllase activity than the green areas.

\section{Total phenols $\left(\mathrm{g} \mathrm{g}^{-1}\right)$}

Blackgram cultivars resistant to $Y M V$ were reported to have high amounts of total phenols than susceptible cultivars. Significant differences were observed among the genotypes. Total phenol content was higher in tolerant genotypes i.e. 20.63 per cent compared to susceptible genotypes. These results are in conformity with the findings of Prabu and Warade (2009) who stated significantly high total phenols in the Okra Yellow Vein Mosaic Virus resistant wild okra and their inter-specific hybrids compared to susceptible cultivated okra cultivar.

Among the tolerant genotypes TBG-104 recorded significantly higher phenol content followed by LBG- 792 whereas, among susceptible genotypes PBG-32 and LBG- 623 genotypes recorded higher and lower phenol content respectively. 
Table.1 Characterization of YMV tolerant and susceptible blackgram genotypes for biochemical parameters and seed yield during rabi 2016-17

\begin{tabular}{|c|c|c|c|c|c|c|}
\hline \multirow[t]{2}{*}{ S. No } & \multirow{2}{*}{$\begin{array}{l}\text { Genotypes } \\
\text { Tolerant }\end{array}$} & \multicolumn{4}{|c|}{ At 50 DAS } & \multirow{2}{*}{$\begin{array}{c}\text { At harvest } \\
\text { Seed Yield } \\
\left(\mathrm{Kg} \mathrm{ha}^{-1}\right)\end{array}$} \\
\hline & & $\begin{array}{c}\text { Total } \\
\text { Chlorophyll } \\
\left(\mathrm{mg} \mathrm{g}^{-1}\right)\end{array}$ & $\begin{array}{c}\text { Total } \\
\text { Phenols } \\
\left(\mathrm{g} \mathrm{g}^{-1}\right)\end{array}$ & $\begin{array}{c}\text { Total Soluble } \\
\text { Sugars (TSS) } \\
\left(\mathrm{g} \mathrm{g} \mathrm{g}^{-1}\right)\end{array}$ & $\begin{array}{c}\text { Total } \\
\text { Protein } \\
\left(\mathrm{mg} \mathrm{g}^{-1}\right)\end{array}$ & \\
\hline 1 & LBG-752 & 1.221 & 10.74 & 0.121 & 0.674 & 1036.47 \\
\hline 2 & PU-31 & 1.085 & 11.47 & 0.124 & 0.735 & 965.53 \\
\hline 3 & GBG-1 & 0.928 & 7.48 & 0.151 & 0.628 & 964.29 \\
\hline 4 & LBG-792 & 1.012 & 7.41 & 0.132 & 0.527 & 807.98 \\
\hline \multirow[t]{3}{*}{5} & TBG-104 & 1.295 & 12.88 & 0.117 & 0.696 & 984.71 \\
\hline & Mean & 1.108 & 10.00 & 0.129 & 0.652 & 951.80 \\
\hline & Susceptible & & & & & \\
\hline 6 & LBG-645 & 1.065 & 6.28 & 0.139 & 0.619 & 775.59 \\
\hline 7 & LBG-623 & 0.841 & 7.74 & 0.220 & 0.359 & 764.67 \\
\hline 8 & LBG-685 & 0.868 & 7.98 & 0.198 & 0.609 & 765.91 \\
\hline 9 & PBG-32 & 0.853 & 11.42 & 0.202 & 0.585 & 768.38 \\
\hline \multirow[t]{5}{*}{10} & PBG-1 & 0.836 & 8.05 & 0.222 & 0.574 & 703.42 \\
\hline & Mean & 0.893 & 8.29 & 0.196 & 0.549 & 755.60 \\
\hline & Grand Mean & 1.001 & 9.15 & 0.163 & 0.601 & 853.69 \\
\hline & SE $\mathbf{m} \pm$ & 0.0993 & 0.6925 & 0.006 & 0.0393 & 1.5646 \\
\hline & $\mathrm{CD}(\mathrm{P}=\mathbf{0 . 0 5})$ & 0.295 & 2.0576 & 0.0178 & 0.1168 & 4.6488 \\
\hline
\end{tabular}

High amount of total phenols in the resistant genotypes were accompanied by increased activities of polyphenoloxidase and peroxidase, resulting in increased oxidation of phenolic substances to form more toxic quinones and others oxidative products which might aid to combat the pathogen in the resistant host.

Total Soluble Sugars (TSS) $\left(\mathrm{g} \mathrm{g}^{-1}\right)$

Total soluble sugars of blackgram susceptible and tolerant genotypes in response to yellow mosaic virus at 30 DAS and 50 DAS during rabi 2016-17.

Significant differences were observed among all genotypes and increasing trend was maintained from 30 DAS to 50 DAS irrespective of genotypes. Tolerant genotypes showed 34.19 per cent reduced mean TSS when compared to susceptible genotypes.
Among the all ten genotypes $\mathrm{PBG}-1$ recorded higher TSS of $0.222 \mathrm{~g} \mathrm{~g}^{-1}$ followed by LBG-623 and PBG-32. Among tolerant genotypes higher and lower TSS was recorded in LBG- 792 and TBG-104 respectively whereas, among susceptible genotypes higher and lower TSS was recorded in PBG-1 and LBG-645 respectively. Similar results for increase of TSS in susceptible blackgram genotypes were observed by Ashfaq et al., 2014.

\section{Total protein $\left(\mathrm{mg} \mathrm{g}^{-1}\right)$}

Significant differences were observed among the genotypes. Tolerant genotypes recorded higher protein content of 3.20 compared to susceptible genotypes. However susceptible genotypes recorded higher increase in TSS content from 30 to 50 DAS compared to tolerant genotypes. The higher percentage seems due to virus multiplication which entails 
the synthesis of virus specific abnormal protein that accumulates an ultimately raises the percentage over healthy. These results for increase of protein content in susceptible genotypes were reported by Kotakadi et al., (2012).

Among all the ten genotypes PU- 31 recorded higher protein content of $0 . \mathrm{mg} \mathrm{g}^{-1}$ followed by TBG- 104 (0.696 $\left.\mathrm{mg} \mathrm{g}^{-1}\right)$ and LBG- 752 (0.674 $\left.\mathrm{mg} \mathrm{g}^{-1}\right)$. Among the tolerant genotypes PU-31 recorded higher protein content $\left(0.735 \mathrm{mg} \mathrm{g}^{-1}\right)$ as well as LBG-792 recorded lower protein content $\left(0.527 \mathrm{mg} \mathrm{g}^{-1}\right)$ whereas, among the susceptible genotypes LBG-645 showed higher protein content $\left(0.619 \mathrm{mg} \mathrm{g}^{-1}\right)$ as well as LBG623 recorded lower protein content $(0.359 \mathrm{mg}$ g $\left.{ }^{1}\right)$.

Total chlorophyll, total phenols, total proteins were significantly decreased whereas total soluble sugars was increased significantly in susceptible genotype (LBG- 623) compared to tolerant genotype (TBG-104). Among all the treatmental sprays tested, combined application of nano and bulk treatmental sprays followed by nano and bulk $\mathrm{Mg}$ sprays showed higher chlorophyll, phenols and proteins whereas lower TSS which enhance YMV tolerance.

\section{References}

Anonymous, 1965. Official Methods of Analysis. Association of official chemists. $10^{\text {th }}$ ed. $139-140$.

Arnon, D.I. 1949. Copper enzymes in isolated chloroplasts. Polyphenol oxidase in Beta vulgaris. Plant Physiology. 24: 1-15.

Ashfaq, M., Khan, A.M., Mukhtar, T and Shahbaz, T.S. 2014. Role of mineral metabolism and some physiological factors in resistance against urdbean leaf crinkle virus in blackgram genotypes. Int J Agric Biology. 16: 189-194.

Devi, C.H. 2016. Morphological and biochemical variability in mungbean yellow mosaic virus (MYMV) resistant and susceptible blackgram genotypes. M.sc. Thesis.

Kessler, A and Baldwin, I.T. 2002. Plant responses to insect herbivory: the emerging molecular analysis. Annu Rev Plant Biol. 53:299-328.

Kotakadi, V.S., Gaddam, S.A and Gopal, D.V.R.S. 2012. Biochemical studies of Sunflower Necrosis Tospovirus infecting sunflower (Helianthus annuus) an edible oilseed crop of India. Journal of Microbiology and Biotechnology Research. 2: 458-463.

Lowry, O.H., Rosebrough, N.J., Fan, A.L and Randall, R.J. 1951. Protein measurement with the folin-phenol reagent. Journal of Biological Chemistry. 193: 265-275.

Mansoor-ul-Hassan, Akbar, R and Latif A. 1998. Varietal response of mung and mash beans to insect attack. Pak Ent.; 20: 43-6.

Prabu, T and Warade, S.D. 2009. Biochemical basis of resistance to Yellow Vein Mosaic Virus in okra. Journal of Vegetable Science. 36: 283-287.

Sadasivam, S and Manickam, A. 1992. In: Biochemical Method for agricultural Sciences, Wiley Eastern Limited, New Delhi. 11-12.

Sharma H. Applications of Biotechnology in Pest Management and Ecological Sustainability. CRC Press Taylor and Francis, Boca Raton, USA, 2009: 526.

\section{How to cite this article:}

Rajitha, B., V. Rajarajeswari, P. Sudhakar, N.V. Naidu, T.N.V.K.V. Prasad and Bhaskara Reddy, B.V. 2018. Biochemical Variability and Seed Yield of Resistant and Susceptible Black Gram (Vigna mungo (L.) Hepper) Genotypes Elicited by Bemisia tabaci (Gennadius). Int.J.Curr.Microbiol.App.Sci. 7(08): 4422-4426. doi: https://doi.org/10.20546/ijcmas.2018.708.466 